\title{
Cissus quadrangularis inhibits IL-I $\beta$ induced inflammatory responses on chondrocytes and alleviates bone deterioration in osteotomized rats via p38 MAPK signaling [Corrigendum]
}

Kanwar JR, Samarasinghe RM, Kumar K, et al. Drug Des

Devel Ther. 2015;9:2927-2940.

The authors have become aware of an error in Figure 6D on page 2936. The corrected figure with the replacement figure part (Figure 6D, W. som image) is provided here.

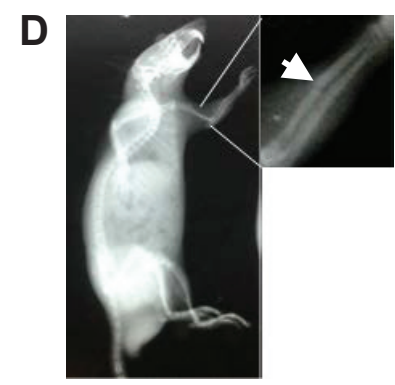

Control

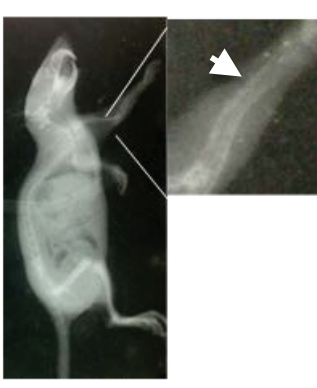

C. quad

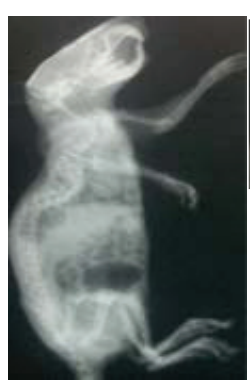

W. som
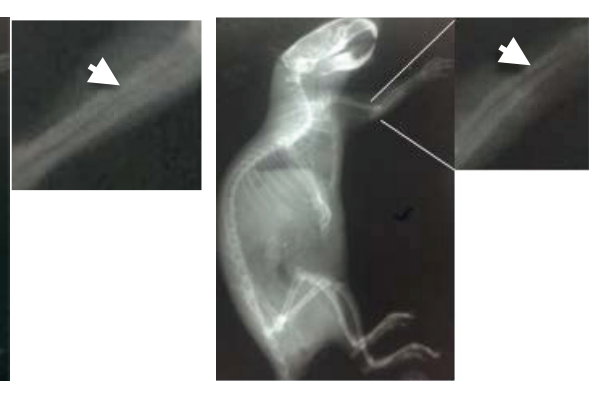

C. quad + W. som

Figure 6

Drug Design, Development and Therapy is an international, peerreviewed open-access journal that spans the spectrum of drug design and development through to clinical applications. Clinical outcomes, patient safety, and programs for the development and effective, safe, and sustained use of medicines are the features of the journal, which has also been accepted for indexing on PubMed Central. The manuscript management system is completely online and includes a very quick and fair peer-review system, which is all easy to use. Visit http://www.dovepress.com/testimonials.php to read real quotes from published authors. 